\title{
Rooting of mini-cuttings of Sequoia sempervirens using different clones and cultural environments
}

\author{
Enraizamiento de miniestaquilla de Sequoia sempervirens \\ utilizando diferentes clones y ambientes culturales
}

\section{Mariane de Oliveira Pereira a , Alessandro Camargo Ângelo a, Marcio Carlos Navroski ${ }^{\mathrm{b} *}$, Marcos Felipe Nicoletti ${ }^{\text {b }}$ Bruno Nascimento ${ }^{\text {b }}$, Alexandra Cristina Schatz Sá ${ }^{\text {, }}$ Luciana Magda de Oliveira ${ }^{\text {b }}$, Queli Cristina Lovatel ${ }^{\text {b }}$}

\author{
a Universidade Federal do Paraná, Av. Prefeito Lothário Meissner, 632 - Jardim Botânico, Curitiba, PR Curitiba, Paraná, Brasil. \\ *Corresponding author: ${ }^{\text {b }}$ Universidade do Estado de Santa Catarina, Av. Luís de Camões, 2090, Lages, SC, Brasil, \\ marcio.navroski@udesc.br
}

\begin{abstract}
SUMMARY
Sequoia sempervirens is a fast-growing, long-lived tree with pest-resistant wood. The objective of this study was to quantify the adventitious rooting ability of sequoia clones in two environments as well as determining rooting behavior during the evaluation period. Mini-cuttings of five clones grown in a clonal mini-garden were planted for rooting in two different environments: a minitunnel and an intermittently fogging greenhouse. Weekly assessments (from 30 to 93 days) of the variables were performed: survival, rooted mini-cuttings and number of roots emitted. Rooting speed varied in relation to the clones, occurring mainly between 50 and 60 days after planting, with the appearance of new roots between 70 and 80 days. The cultivation environment promoted distinct responses in the rooting process, being earlier in the greenhouse environment, although with a higher index in the mini-tunnel at the end of the evaluation. The process of differentiation of mini-cuttings occurs initially with the formation of calluses, around 15 days, followed by rooting (between 30 and 60 days) and the subsequent appearance of new roots. The rooting of sequoia mini-cuttings can be done in a mini-tunnel, with good indexes for all clones. It is recommended to keep mini-cuttings in this environment for 90 days for good root formation.
\end{abstract}

Key words: vegetative propagation, greenhouse, mini-tunnel, rooting speed, logistic model.

\section{RESUMEN}

Sequoia sempervirens es un árbol longevo de rápido crecimiento con madera resistente a plagas. El objetivo de este estudio fue cuantificar la capacidad de enraizamiento adventicio de clones de S. sempervirens en dos ambientes, así como determinar el comportamiento de enraizamiento durante el período de evaluación. Se plantaron miniestaquillas de cinco clones cultivados en minihuertos clonales para enraizar en dos ambientes diferentes: mini túnel e invernadero de nebulización intermitente. Se realizaron evaluaciones semanales (de 30 a 93 días) de las variables: supervivencia (\%), mini estaquillas enraizadas (\%) y raíces emitidas. La velocidad de enraizamiento varió en relación con los clones, ocurriendo principalmente entre 50 y 60 días después de plantados, con la aparición de nuevas raíces entre 70 y 80 días. El ambiente de cultivo promovió respuestas distintas en el proceso de enraizamiento, siendo más temprano en el invernadero de nebulización intermitente, pero con un índice más alto en el mini túnel al final de la evaluación. El proceso de diferenciación de mini estaquillas ocurrió inicialmente con la formación de callos, alrededor de 15 días, seguido de enraizamiento (entre 30 y 60 días) y la posterior aparición de nuevas raíces. El enraizamiento de las mini estaquillas se puede hacer en un mini túnel, con buenos índices para todos los clones, y se recomienda mantener las mini estaquillas en este ambiente durante 90 días para una buena formación de raíces.

Palabras clave: propagación vegetativa, invernadero, mini túnel, velocidad de enraizamiento, modelo logístico.

\section{INTRODUCTION}

Sequoia sempervirens ((D. Don) Endl.) (sequoia) is a species of natural occurrence restricted to the coast of California and southwestern of Oregon, generally in an irregular coastal zone of $725 \mathrm{~km}$ long and 8-56 km wide (Ahuja
2009). Although the sequoia develops in humid places and at altitudes ranging from 30 to $760 \mathrm{~m}$, its dispersion can extend to $915 \mathrm{~m}$ above sea level. It is a fast-growing tree, reaching a growth rate of 1-1.5 meters per year, with the largest trees reaching heights superior to $110 \mathrm{~m}$ (Olson et al. 1990). Sequoia wood is reddish, usually called redwood. It presents 
low density ( 0.40 to $\left.0.45 \mathrm{~g} \mathrm{~cm}^{-3}\right)$, being easy to work and resistant to pests that attack wood. Its phenolic products confer exceptional chemical stability and can be used for raw wood, unfolding and paper production (Gale 1962).

Sequoia shows reproduction mainly by seeds and, often, by basal shoots (Ahuja 2009). Seed reproduction is a barrier to large-scale breeding, as seed germination rate is very low (mean $10 \%$ ) (Boe 1974). For asexual reproduction, classic literature has reported that the species has the potential for propagation by cuttings (Metcalfe 1924), nevertheless no large-scale attempt for this type of reproduction had been reported until the 1960's (Roy 1966). The first studies on vegetative propagation by cuttings began around 1970. Already in the first studies, the necessity to use basal shoots obtained from cut of the trunk or the stimulation by hot water in the roots was evidenced.

The use of vegetative propagation can overcome the problems reported with the use of seeds, besides making it possible to increase production in a shorter period (Stuepp et al. 2013), to select genotypes of interest and to produce uniform populations with a larger phase control of development (Hartmann et al. 2011). Among the vegetative propagation methods, the mini-cutting technique shows effective and relatively fast results for obtaining clones (McMahon et al. 2014). This technique has some advantages, such as the reduction of the size of the propagules, increasing in the productivity of shoots per area and better rooting, often without the need to use growth regulators (Stuepp et al. 2015).

Several factors influence the performance of minicuttings, especially the environmental conditions to which the propagules are exposed during the adventitious rooting stage, directly interfering with the survival and percentage of rooting (Brondani et al. 2018). The temperature and relative humidity of the air in the rooting environment are emphasized among the factors and have direct implications in the physiological processes. To maintain adequate temperature and humidity for rooting, appropriate structures are required in the nursery phase. The advancement of technology has allowed the development of infrastructure used in the propagation of plants, such as nebulization chambers and greenhouses, often equipped with automated systems. However, intermittent misting systems are costly installations, hence to use this technology is unfeasible for smaller producers.

For small-scale and simple production of the plants, the construction of small greenhouses using low-cost materials (Vieira Neto et al. 2010) may be feasible. However, some studies have been developed with this proposal, with good results (Almeida et al. 2008, Brondani et al. 2018). Another factor that represents an important point for research, having direct effects on breeding gains, is the clonal effect on rooting. The ability to form adventitious roots in vegetative propagules is very restricted and the selection of specific genotypes may allow propagation of the species with future gains.
During the rhizogenic process the formation of groups of meristematic cells occurs, also happens at this stage the differentiation of these groups of cells in primitive roots and the development and emergence of the new roots, including the rupture of other tissues of the stem and the formation of vascular connections with the tissues conducting the cuttings (Hartmann et al. 2011). Only from the formation of root primordia is it possible to observe the appearance of roots. The determination of these phases is important for the creation of a pattern of rooting time, period in which each clone needs to remain in the rooting environment. This type of study is important, especially for sequoia, since there are no reports of studies in this sense.

This article is part of a project that aims at producing and cultivating the species in Brazil, through research involving selection of superior materials, vegetative propagation and clonal field tests. Our hypothesis for this study is that there is a difference in rooting of mini-cuttings among clones of Sequoia sempervirens, and that this may serve to select superior genetic material for this trait. In addition, these clones may respond differently depending on the rooting environments they are conditioned. This response can guide producers in the process of plants production. Likewise, we wanted to show by means of a mathematical model how the process of formation and development of roots occurs along the time of propagation, aiming at determining the time of maintenance of minicuttings in rooting environment.

In this way, the objective of this work is to identify the better environment for rooting of mini-cuttings of different clones of Sequoia sempervirens, besides determining the dynamics of rooting through mathematical modeling behavior in the root formation during the evaluation period.

\section{METHODS}

Propagule sources for the test were selected from sequoia matrices (located in Sao Francisco de Paula, Rio Grande do Sul state, Brazil $\left(29^{\circ} 27^{\prime} 44^{\prime \prime} \mathrm{S}\right.$ and $\left.50^{\circ} 24^{\prime} 11^{\prime \prime} \mathrm{W}\right)$ of approximately 40 years of age. The area is part of a sequoia plantation carried out between 1974 and 1975 (no correct definition date). Planted seedlings were originated from seeds from California (USA). The vegetative material was propagated by the conventional cutting technique, 120 days after total girdling or partial girdling of the parent plant. The material was collected from the parent trees and transported in Styrofoam ${ }^{\circledR}$ boxes with ice in the background (transport lasted approximately 4 hours) to the Forest Nursery located at University of the State of Santa Catarina- UDESC (Lages, Santa Catarina state, Brazil $-27^{\circ} 47^{\prime} 33^{\prime \prime} \mathrm{S}$ and $50^{\circ} 18^{\prime} 04^{\prime \prime} \mathrm{W}$ ). After that, cuttings with a size of $10 \mathrm{~cm}$ containing a pair of acicular leaves were reduced to $50 \%$ of the leaf area and treated with 6000 $\mathrm{mg} \mathrm{L}^{-1}$ of indole-3-butyric acid (IBA). Afterwards, they were inserted in tubes $\left(180 \mathrm{~cm}^{-3}\right)$ containing vermiculite of medium granulometry and commercial substrate (peat, ex- 
panded vermiculite, pine bark and charcoal) and arranged in a mini-tunnel for rooting.

After cutting, five-month-old rooted cuttings were acclimatized in a shade house (covered with shading screen $30-35 \%$ and average $23{ }^{\circ} \mathrm{C}$ ) for 30 days and transferred to the greenhouse (covered with low-density polyethylene and average $28{ }^{\circ} \mathrm{C}$ ) to complete the acclimation for 30 days more. Subsequently, plants with approximately 20 $\mathrm{cm}$ of height were transferred to pots with $5 \mathrm{~L}$ capacity, filled with commercial substrate $(50 \%)$ (the same used for cutting) and vermiculite of medium granulometry (50\%) was added. Fifteen days after the installation, the time necessary to adapt the plants to the system, the apex of the plant main bud was cut at a height of $10 \mathrm{~cm}( \pm 2 \mathrm{~cm})$, forming the mini-stumps for the establishment of the clonal mini-garden. During four months, monthly pruning of the mini-stumps was carried out.

The nutrient solution used in the clonal mini-garden was commercial fertilizer composed by: $10 \% \mathrm{~N}$ (water soluble), $42 \% \mathrm{P}_{2} \mathrm{O}_{5}$ (water soluble), $10 \% \mathrm{~K}_{2} \mathrm{O}$ (water soluble), $0.6 \% \mathrm{Mg}, 0.1 \% \mathrm{Fe}$ and $0.02 \mathrm{~B}$. Fertigation was done twice a week, with each mini-stump receiving $50 \mathrm{~mL}$ of solution composed by diluting 1.5 grams of the fertilizer per liter of water. After the period of formation of the mini-stumps, the sprouts were collected to perform the experiments.

Five clones with higher availability of propagating material from the clonal mini-garden, named A113, A116, A140, A227 and A228 were used, constituting the factor "A" of the experiment. The shoots obtained from these clones were prepared mini-cuttings with 8 to $10 \mathrm{~cm}$ in length with a pair of acicular leaves reduced to $50 \%$ of the leaf area.

The mini-cuttings were placed in $180 \mathrm{~cm}^{3}$ polypropylene tubes, containing vermiculite of medium granulometry and commercial substrate $(1: 1, \mathrm{v} / \mathrm{v})$, where the insertion of approximately $2 \mathrm{~cm}$ of the base of the mini-cutting in the substrate was carried out, without the use of growth regulator. According to the manufacturer's description the commercial substrate used consists of peat, expanded vermiculite, pine bark and charcoal. The chemical and physical characteristics according to substrate analysis were: $\mathrm{pH}$ = 6.6; electrical conductivity $=0.13 \mathrm{mS} \mathrm{cm}^{-1}$; wet density $=450.8 \mathrm{~kg} \mathrm{~m}^{-3} ;$ dry density $=302.7 \mathrm{~kg} \mathrm{~m}^{-3}$; current humidity $=32.8(\%)$; total porosity $=72.2(\%)$; aeration space $=17.0(\%)$; readily available water $=12.2(\%)$; buffer water $=2.4(\%)$; remaining water $=40.5(\%)$; CRA10 - water holding capacity at $10 \mathrm{~cm}=55.1$; CRA50 $=42.9$ and CRA100 $=40.5$.

After planting, the tubes containing the mini-cuttings were conditioned in two different rooting environments (factor B): a mini-tunnel, located in the UDESC Forest Nursery, and a greenhouse intermittently fogging (GIF) of a forest company located in Otacílio Costa (Brazil). The mini-tunnel is a simple structure with plastic cover, showing $8.0 \times 1.20 \times 0.9 \mathrm{~m}$ (length $\mathrm{x}$ width $\mathrm{x}$ height), located under the shade house. The GIF is automated, with temperature control (general temperature between $20-30{ }^{\circ} \mathrm{C}$ ) and relative humidity ( $\mathrm{RH}>80 \%$ ); both variables were controlled automatically by thermostat and humidistat. The preparation and planting of the material in the containers were carried out in the UDESC Forest Nursery. The pots were transported soon after the procedure to the nursery of Otacílio Costa and kept in an air-conditioned environment during the trip, not exceeding one hour of travel between the two nurseries.

The water management in the mini-tunnel included five irrigations daily (09:00 a.m.; 11:30 a.m.; 01:30 p.m.; 3:30 p.m.; 6:00 p.m) of 7 minutes each, using the micro sprinkler system. In the GIF, irrigation was performed by nebulization, with variable periods according to humidity and temperature. At both places, the data collection of moisture and temperature was performed by means using Politerm datalogger, model Pol-49, with the readings being performed every 10 minutes. The average weekly values of temperature and humidity in the two rooting environments can be observed in figure 1 .

The experiment was conducted during the first week of April until the first week of July (2017), under a completely randomized design, in a $5 \times 2$ factorial scheme (five clones and two environments), using five replicates of 50 mini-cuttings per unit (five mini-cuttings per replicate at each evaluation). Weekly evaluations were carried out (10 weeks), starting from the $30^{\text {th }}$ day after planting, until the $93^{\text {rd }}$ day, when there was stabilization of the rooting. Minicuttings evaluated in one period were no longer used in the next evaluations to avoid interference with the withdrawal and replacement of the same.

The survival of mini-cuttings (\%), callus formation $(\%)$, rooting (\%), a number of roots emitted by root minicutting and root origin were evaluated. Survivors were mini-cuttings that had live wood, old leaves or young shoots, rooted or not. The percentage of rooted mini-cuttings was considered on the total, not only on the surviving. Rooted mini-cuttings were those that had root primordia larger than $2 \mathrm{~mm}$. To determine the origin of the roots, the site was classified into: roots with origin of callus (figure 2A), roots with origin in the woody tissue (it could be of the cortex, exchange, vascular ray or parenchyma of the phloem) (figure 2B) and in both sites (figure 2C).

After checking the normality of the data by the Kolmogorov-Smirnov test and the homogeneity by the Bartlett test, the statistical analysis was performed. When necessary, the data were transformed by the function $(x+0.5)$ 0.5 . The data of the final evaluation (93 days) were submitted to analysis of variance and when there was significant difference by the $F$ test the means were compared by the Scott-Knott test (clone factor) or $t$ test (local factor) at $5 \%$ probability. The analyses were applied by the statistical program R software.

The data distributions of the two variables were then adjusted using an appropriate regression model for estimating the rooting of mini-cuttings according to the evaluation on the time. After testing by linear, exponential, poly- 
nomial and logistic models, the logistic model showed the best-fitting results. For the logistic regression, three models were tested: with four parameters, with three parameters, and an asymptotic. Their quality was further evaluated to select the best model, using the Akaike information criterion (AIC) (Akaike 1973), the Bayesian criterium (BIC) and the standard error of the estimate $\left(\mathrm{S}_{\mathrm{yx}}\right)$. The logistic function is used to describe changes in the dependent variable (in the case of this study survival (\%), callus formation $(\%)$, rooting $(\%)$ and number of roots) as a function of time. The logistic regression model of this work was then adjusted according to the function with four parameters [1]:

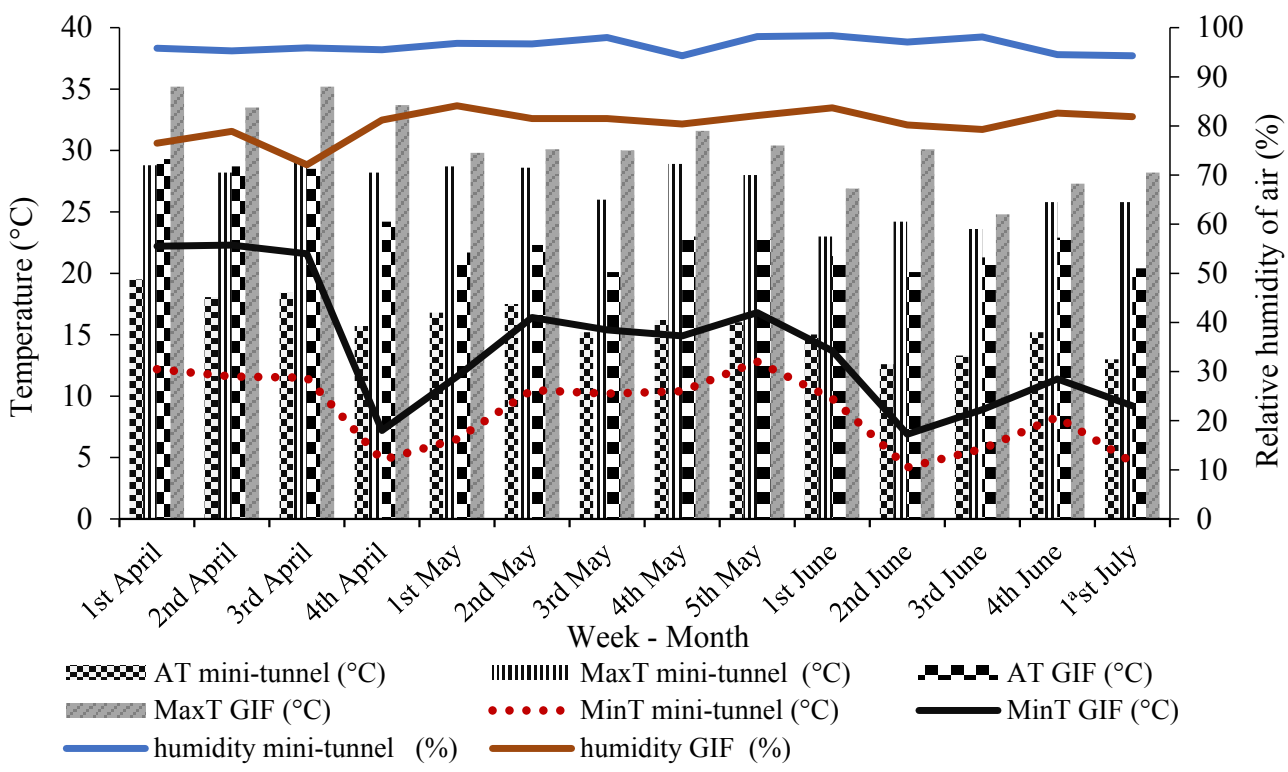

Figure 1. Weekly averages (first week of April to first week of July) of average temperature - AT $\left({ }^{\circ} \mathrm{C}\right)$, maximum temperature - MaxT $\left({ }^{\circ} \mathrm{C}\right)$, minimum temperature - $\operatorname{MinT}\left({ }^{\circ} \mathrm{C}\right)$ and average relative humidity - humidity $(\%)$ in the two environments (mini-tunnel and greenhouse intermittently fogging - GIF) in the rooting of mini-cuttings of Sequoia sempervirens.

Promedios semanales (desde la primera semana de abril hasta la primera semana de julio) de temperatura promedio - AT $\left({ }^{\circ} \mathrm{C}\right)$, temperatura máxima - MaxT $\left({ }^{\circ} \mathrm{C}\right)$, temperatura mínima - $\operatorname{MinT}\left({ }^{\circ} \mathrm{C}\right)$ y humedad relativa promedio - humedad $(\%)$ en los dos ambientes (mini túnel e invernadero de nebulización intermitente - GIF) durante el enraizamiento de mini estaquilla de Sequoia sempervirens.
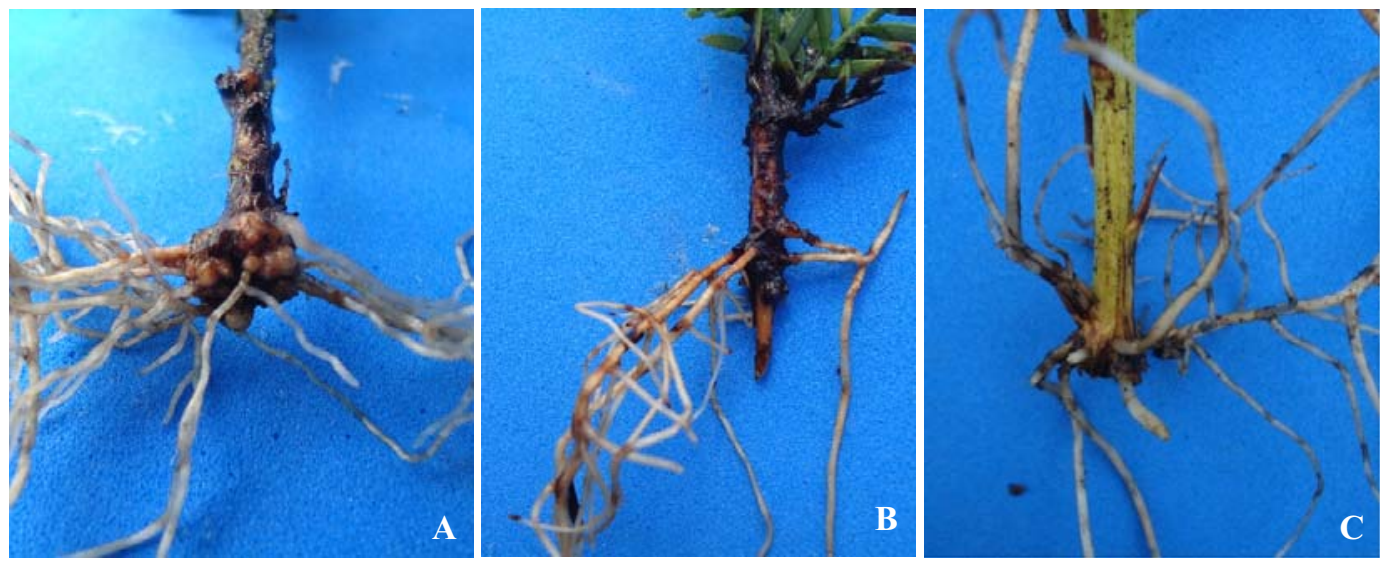

Figure 2. Roots origin in Sequoia sempervirens mini-cuttings; A) roots with origin of callus; B) roots with origin in the woody tissue and, C) roots emerging from calluses and woody tissue.

Origen de las raíces en mini estaquilla de Sequoia sempervirens; A) Raíces con origen de callo; B) raíces con origen en el tejido leñoso y, C) raíces que emergen de callos y tejido leñoso. 


$$
V i=\varphi 1+\frac{\varphi 2-\varphi 1}{1+\exp [(\varphi 3-T i) / \varphi 4]}+\varepsilon i
$$

Where: $V i=$ Variable observed in the $\mathrm{i}^{- \text {th }}$ mini-cutting; $T i=$ time of the $\mathrm{i}^{\text {th }}$ mini-cutting regarding the days after planting; $\varphi i=$ regression coefficients and $\varepsilon i=$ random error.

The parameter $\varphi_{1}$ is the upper horizontal. The parameter $\varphi_{2}$ is the lower horizontal asymptote where the variable goes to positive infinity. The parameter $\varphi_{3}$ is the middle response parameter, which represents the variable value at the inflection point, when the response is $\left(\varphi_{1}-\varphi_{2}\right) / 2$, i.e. halfway between the upper and lower asymptote. The parameter $\varphi_{4}$ is the scale parameter.

With the equation obtained for each clone and site, the maximum rooting potential expressed by the coefficient $\varphi_{2}$ was determined. The functions were adjusted for each rooting site, for each clone and for the variation of the clones at each site. Weekly, starting from the 15 day, the development of calluses and roots were recorded through photographs, seeking to create a pattern of root development.

\section{RESULTS}

For survival (\%) and callus formation (\%) in the sequoia mini-cuttings in the different evaluation periods, due to the clones and rooting sites, there was no significance and adjustment of the original logistic function, or any of the equations tested. Mean survival was $98 \%$ and callus mean was $35.5 \%$, considering weekly evaluations of 30 to 93 days in both sites and for the five clones tested. About rooting, based on the shape of the curve and the estimates of the parameters $\varphi$, it was possible to verify that there are differences in the rooting percentage in the evaluated rooting environment (mini-tunnel and GIF) and in the five clones tested (figure 3 ).

In clones A113, A116 and A140, the rooting started earlier in the GIF than in the mini-tunnel. At 30 days, there was no rooting of mini-cuttings in the mini-tunnel, while in GIF, rooting of clones A113 and A140 were observed. In clone A113 rooting progressively increased in GIF until approximately 80 days after planting, when there was stabilization of the curve. In the mini-cuttings kept in the mini-tunnel, rooting only occurred after the $50^{\text {th }}$ day. However, rooting reached stabilization $\left(\varphi_{2}\right)$ at 60 days. The clone A113 presented final rooting near $80 \%$ in both rooting environment $\left(\varphi_{2}\right.$ mini-tunnel $=82.27 \%$ and $\varphi_{2} \mathrm{GIF}=$ $87.46 \%$ ).

Rooting in GIF also started previously (evaluation at 37 days) for clone A116, reaching stabilization near 60 days. In this environment, the maximum final rooting was less than $90 \%$, being smaller in relation to the minicuttings kept in the mini-tunnel, which presented $100 \%$ 80 days after planting. The clone A140 exhibited a similar rooting percentage in both environments, being higher in the mini-tunnel at the end of the evaluation. It is important to emphasize the precocity in the rooting of this clone in relation to the others, because before the 60 days more than $80 \%$ of the mini-cuttings already had roots.

The most important difference in rooting between the two environments was observed for clone A227, which had a final rooting slightly higher than $50 \%$ in $\operatorname{GIF}\left(\varphi_{2}=\right.$ 52.543 ) and $100 \%$ in the mini-tunnel. Probably this result is due to the interaction of genetic characteristics of the clone versus environmental effect. Unlike clone A227, clone A228 showed similarity in rooting percentage. Only after 70 days were better results observed for the mini-tunnel, in which there was also higher final rooting for this clone.

In relation to the number of roots per mini-cutting there was variation in each clone (figure 4). For clones A116 and A140 the GIF presented the best results, exceeding 10 roots per mini-cutting. For clones A227 and A228, the mini-tunnel environment provided improvement in rooting, ranging from 6 to 10 roots in the last evaluation (93 days). Clone A113 presented similar behavior at 93 days of evaluation in both environments.

In the analysis of variance, using data only from the last evaluation (93 days), there was no difference for survival, with the overall mean of $98 \%$. The callus formation $(P=0.045)$, rooting $(P=0.0049)$ and number of roots $(P$ $=0.0023)$ showed interaction between the environment (mini-tunnel and GIF) and clones.

In relation to callus formation, mini-cuttings in the mini-tunnel showed higher callogenic formation (table 1). Clone A228 presented the highest average and clone A140 the lowest percentage. Rooting showed no difference among the clones in the mini-tunnel, with results higher than $85 \%$. In the GIF, the clone A227 showed inferior rooting (also in relation to the mini-tunnel), the only one with a value lower than $85 \%$. Regarding the number of roots, there was also no difference among the clones, with each mini-cutting showing approximately five to nine roots. In the GIF there was a considerable difference among the clones, ranging from 4.1 (A227) to 14.7 (A140). Between the environments, mini-cuttings maintained in GIF presented higher values for clones A116 and A140.

The root origin shows high variation among the evaluated clones. Most clones present callus as root origin, except for clones A116 and A228 in which woody tissue or both sites (callus and woody tissue) predominate as root origin (table 2).

The process of differentiation of mini-cuttings aiming at root development starts, in most experiments, with callus formation. At about 15 days (the $3^{\text {rd }}$ week after planting), the visual appearance of this type of structure at the base of the mini-cutting begins, usually with small structures and with clear appearance (figure 5A). Rooting for most of the tested clones starts from the $4^{\text {th }}$ and $5^{\text {th }}$ week (figure 5B), which originates from the callus or woody tissue, presenting initially few roots with important thickness 
Clone 113

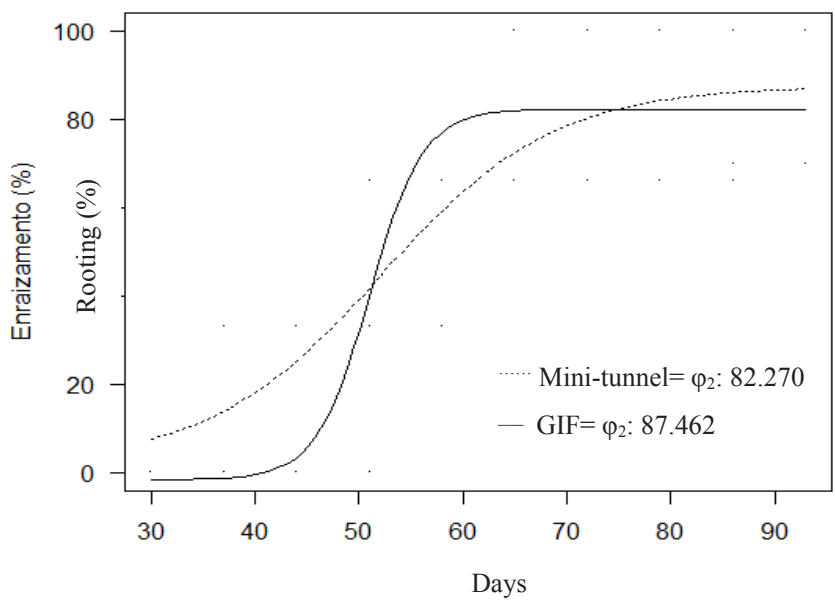

Clone 140

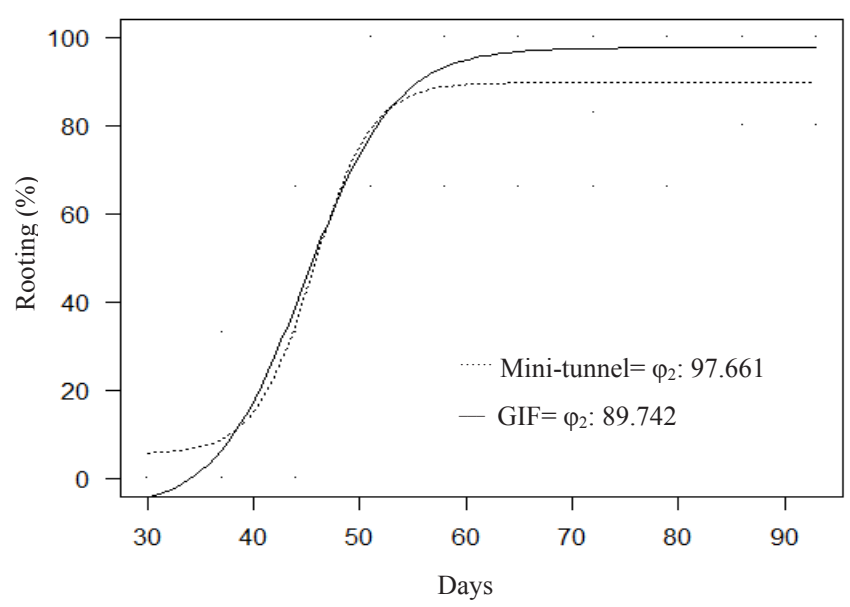

Clone 116

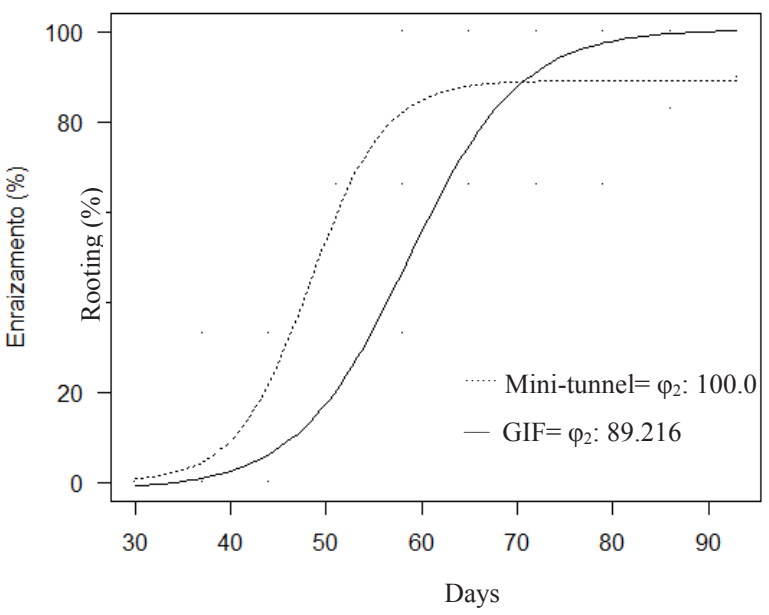

Clone 227

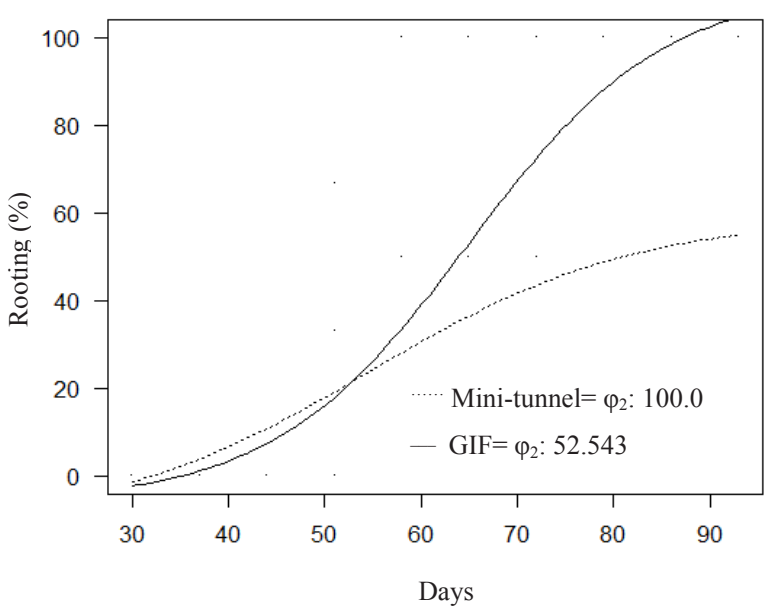

Clone 228

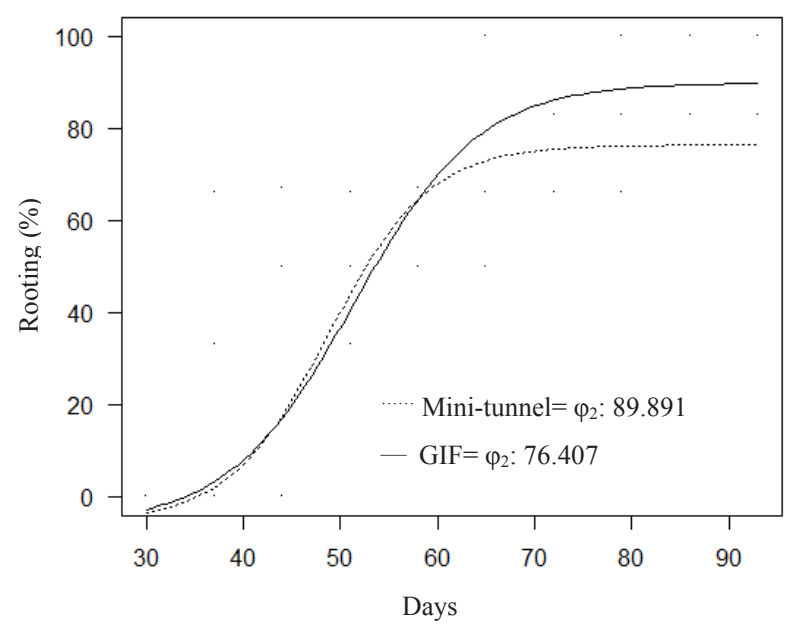

Figure 3. Rooting of Sequoia sempervirens clones as a function of time in greenhouse intermittently fogging (GIF) and mini-tunnel. $\varphi_{2}$ : coefficient of the maximum potential of rooting. Weekly, starting from the 15 day, the development of calluses and roots were recorded through photographs, seeking to create a pattern of root development.

Enraizamiento de clones de Sequoia sempervirens en función del tiempo de residencia en el invernadero de nebulización intermitente (GIF) y mini tunel. $\varphi_{2}$ : coeficiente del potencial máximo de enraizamiento. A partir del día 15, el desarrollo de callos y raíces fue registrado semanalmente mediate fotografías para crear un patrón de desarrollo radical. 
Clone 113

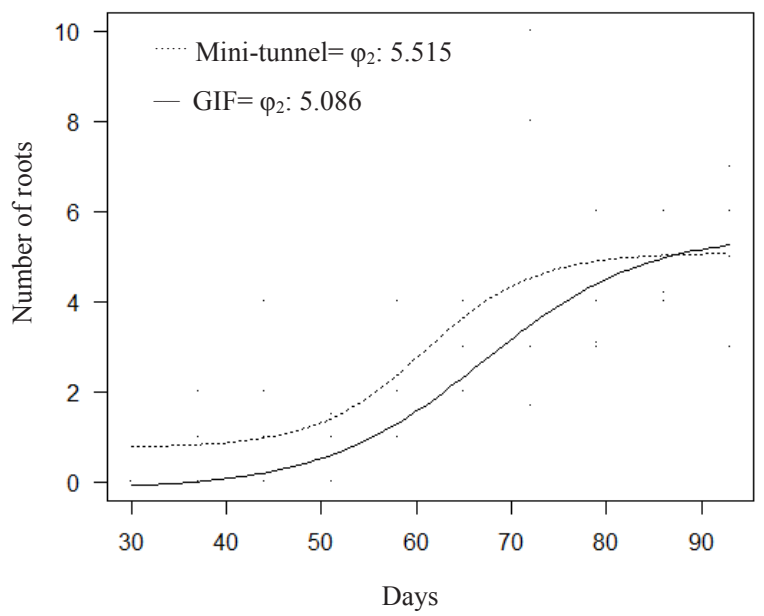

Clone 140

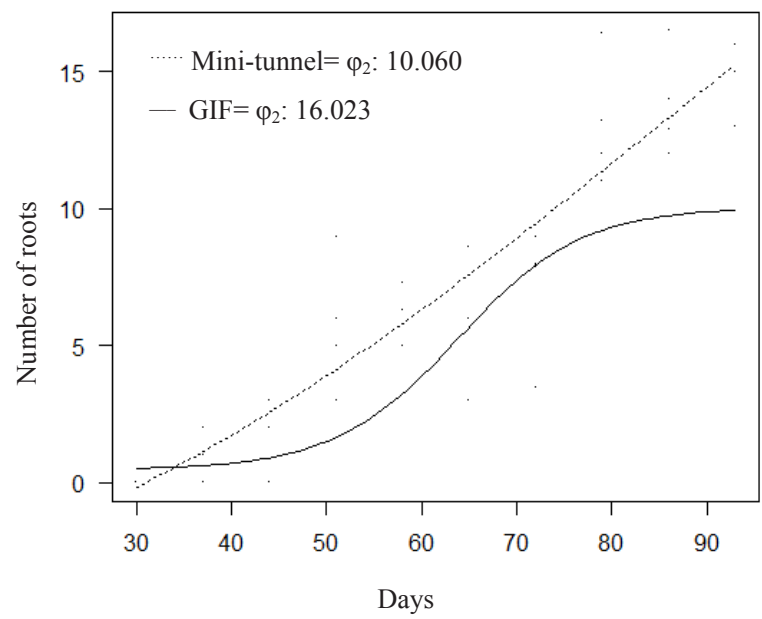

Clone 116

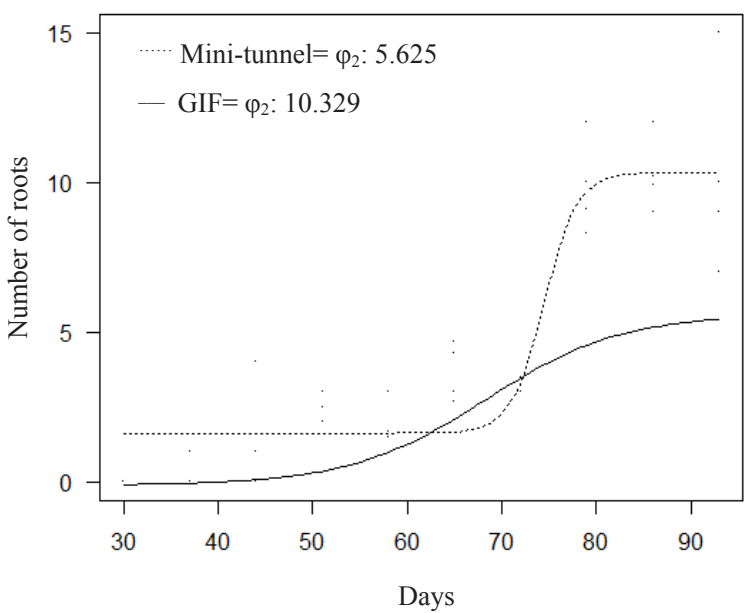

Clone 227

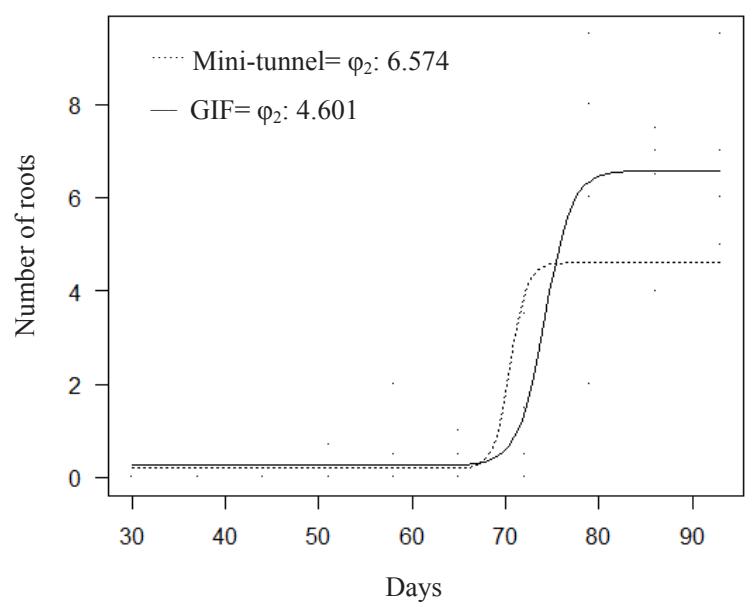

Clone 228

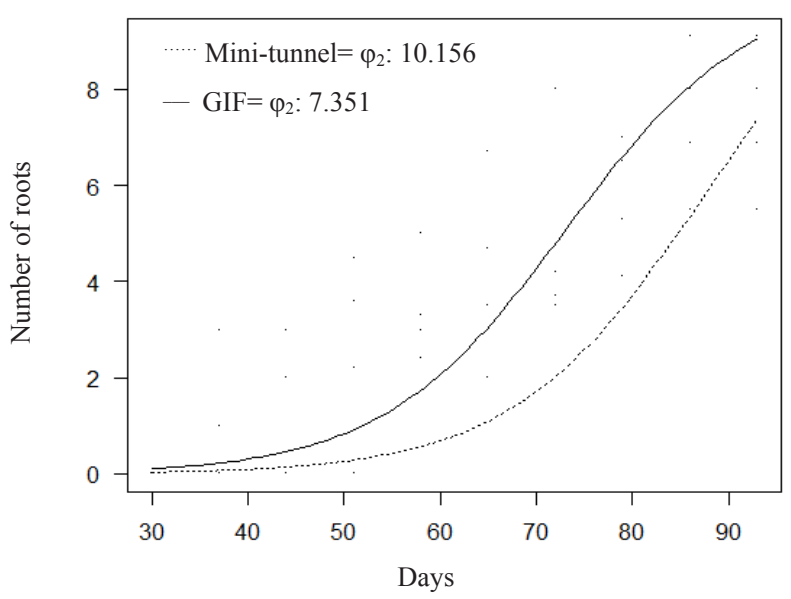

Figure 4. Number of roots in mini-cuttings of Sequoia sempervirens clones as a function of time in greenhouse intermittently fogging (GIF) and mini-tunnel. $\varphi_{2}$ : coefficient of the maximum potential of rooting.

Número de raíces en mini estaquillas de clones de Sequoia sempervirens en función del tiempo de residencia en el invernadero de nebulización intermitente (GIF) y mini tunel. $\varphi_{2}$ : coeficiente del potencial máximo de enraizamiento. 
(figure $5 \mathrm{C}$ and $5 \mathrm{D}$ ). From the $6^{\text {th }}$ to $7^{\text {th }}$ week (between 40 - 50 days) a progressive increase in rooting (figure $5 \mathrm{E}$ ) and the emergence of more fine roots occur. After the $8^{\text {th }}$ week (and observed until the $13^{\text {th }}$ ), there was a high increase in

Table 1. Callus formation (\%), rooting (\%) and number of roots in mini-cuttings of Sequoia sempervirens in relation to the use of different clones and environments, 93 days after planting.

Formación de callos (\%), enraizamiento (\%) y número de raíces en mini estaquillas de Sequoia sempervirens en relación con diferentes clones y ambientes, 93 días después de plantados.

\begin{tabular}{lcc}
\hline \multirow{2}{*}{ Clone } & Mini-tunnel & GIF \\
& & Creenhouse intermittently fogging \\
\hline A113 & $62.5 \mathrm{Ab}^{1}$ & $49.5 \mathrm{Ab}$ \\
A116 & $87.5 \mathrm{Aa}$ & $31.0 \mathrm{Bb}$ \\
A140 & $50.0 \mathrm{Ab}$ & $18.7 \mathrm{Bc}$ \\
A227 & $50.0 \mathrm{Ab}$ & $72.5 \mathrm{Aa}$ \\
A228 & $87.5 \mathrm{Aa}$ & $89.0 \mathrm{Aa}$ \\
\hline & & $85.0 \mathrm{Aa}$ \\
\hline A113 & $87.5 \mathrm{Aa}$ & $95.0 \mathrm{Aa}$ \\
A116 & $100.0 \mathrm{Aa}$ & $95.0 \mathrm{Aa}$ \\
A140 & $100.0 \mathrm{Aa}$ & $58.0 \mathrm{Bb}$ \\
A227 & $100.0 \mathrm{Aa}$ & $95.7 \mathrm{Aa}$ \\
A228 & $93.7 \mathrm{Aa}$ & Rooting $(\%)^{*}$ \\
\hline & & Number of roots* \\
\hline A113 & $6.0 \mathrm{Aa}$ & $10.5 \mathrm{Ab}$ \\
A116 & $5.3 \mathrm{Ba}$ & $14.7 \mathrm{Aa}$ \\
A140 & $8.9 \mathrm{Ba}$ & $4.1 \mathrm{Ac}$ \\
A227 & $6.8 \mathrm{Aa}$ & $7.4 \mathrm{Ac}$ \\
A228 & $8.7 \mathrm{Aa}$ & \\
\hline
\end{tabular}

${ }^{1}$ Means followed by upper in the line and lower case letters in columns do not differ by the Scott-Knott test (clone factor) and $t$ test (local environment), at $5 \%$ probability. $*=P<0.001$. the number of roots, and the mini-cutting was observed to present growth of the aerial part, developing an apical dominance (figure 5F, $5 \mathrm{G}$ and $5 \mathrm{H}$ ).

\section{DISCUSSION}

Survival was high in the sequoia mini-cuttings, showing good control of the environment conditions for maintenance of the material during the rooting process, regardless of the site (mini-tunnel or GIF). In addition, it can be observed that the species has a potential for propagation by the mini-cutting technique, and is similar to classical species in the propagation by cloning in Brazil, especially the genus Eucalyptus (Brondani et al. 2010, Borges et al. 2011).

Regarding rooting, the difference between the minicuttings maintenance sites shows the importance of the environment conditions to maximize the rooting. In the GIF, rhizogenic process started earlier for most of the clones, and it was possible to observe mini-cuttings rooted as early as 30 days. This rapid rooting is surprising when it comes to a species of conifer that generally has low indexes and slower processes, especially in important genera such as Picea, Tsuga, Abies and Pinus (Hartmann et al. 2011). This result, besides the environment conditions, which will be treated next, is attributed to the process of reinvigoration in vegetative rescue, when full or partial girdling was used, and to rejuvenation with the use of successive pruning in the clonal mini-garden (Wendling et al. 2014).

The highest temperature obtained in the GIF (figure 1) was responsible for the early rooting contrasted with the mini-tunnel in most of the clones. The mean temperature obtained in the GIF during the first 30 days was around 25 to $28^{\circ} \mathrm{C}$. On the other hand, the average was less than $20{ }^{\circ} \mathrm{C}$. With this, the species shows a certain preference for higher temperatures in the initial phase of cell differentiation and root development. Lower temperatures may inhibit the activity of endogenous auxins (Corrêa and FettNeto 2004). Studies have shown that there is a reduction of

Table 2. Origin of the roots (callus, woody tissue or callus and woody tissue) in different clones of Sequoia sempervirens during the rooting process. enraizamiento.

Origen de las raíces (\%) (callo, tejido leñoso o callo y tejido leñoso) en los diferentes clones de Sequoia sempervirens durante el proceso de

\begin{tabular}{cccc}
\hline \multirow{2}{*}{ Clone } & \multicolumn{3}{c}{ Origin of the roots $(\%)$} \\
\cline { 2 - 4 } & Callus* & Woody tissue* & Callus and woody tissue* \\
\hline A113 & $54.5 \mathrm{~b}^{1}$ & $38.6 \mathrm{a}$ & $6.9 \mathrm{a}$ \\
A116 & $29.5 \mathrm{a}$ & $34.1 \mathrm{a}$ & $36.4 \mathrm{~b}$ \\
A140 & $50.0 \mathrm{~b}$ & $31.2 \mathrm{a}$ & $18.8 \mathrm{a}$ \\
A227 & $48.7 \mathrm{~b}$ & $25.6 \mathrm{a}$ & $25.7 \mathrm{~b}$ \\
A228 & $33.3 \mathrm{a}$ & $31.3 \mathrm{a}$ & $35.4 \mathrm{~b}$ \\
\hline
\end{tabular}

${ }^{1}$ Averages followed by equal letters in the columns do not differ by Scott-Knott's test, at $5 \%$ probability. * $=P<0.001$. 

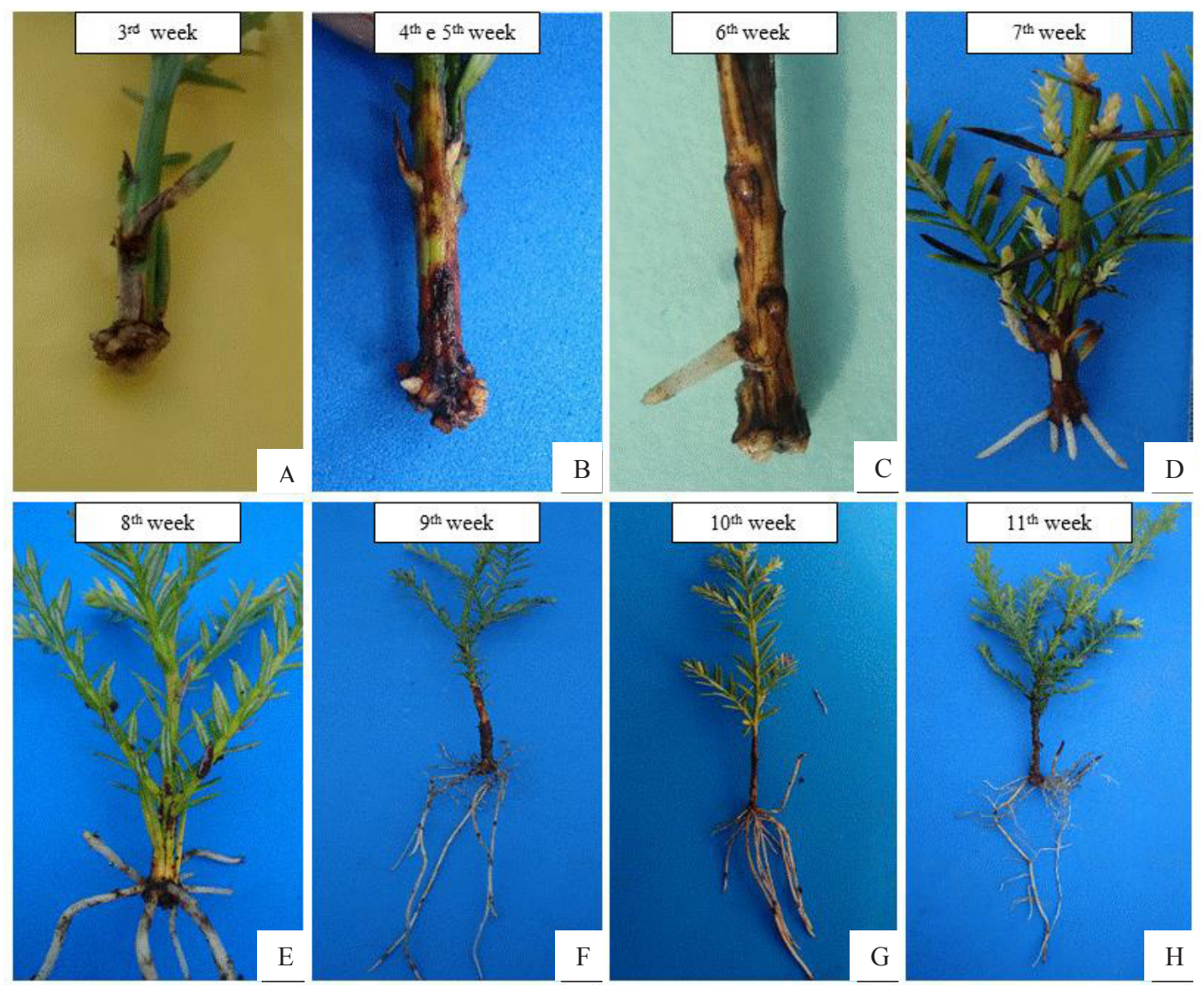

Figure 5. Evolution in the mini-cutting rooting process of Sequoia sempervirens after planting: A) $3^{\text {rd }}$ week; B) $4^{\text {th }}$ and $5^{\text {th }}$ week; C) $6^{\text {th }}$ week; D) $7^{\text {th }}$ week; E) $8^{\text {th }}$ week; F) $9^{\text {th }}$ week; G) $10^{\text {th }}$ week and H) $11^{\text {th }}$ week.

Evolución en el proceso de enraizamiento de mini estaquillas de Sequoia sempervirens después de: A) $3^{\mathrm{a}}$ semana; B) $4^{\mathrm{a}}$ y $5^{\mathrm{a}}$ semana; C) $6^{\mathrm{a}}$ semana; D) $7^{\mathrm{a}}$ semana; E) $8^{\mathrm{a}}$ semana; F) novena semana; G) $10^{\mathrm{a}}$ semana y H) $11^{\mathrm{a}}$ semana.

basal IAA (indole acetic acid) transport when the temperature is reduced from $25^{\circ} \mathrm{C}$ to $4{ }^{\circ} \mathrm{C}$ (Garrido et al. 2002), which may influence the decrease of the root induction in the mini-cuttings during the colder seasons or slow process of differentiation. In this study, minimum temperatures were recorded in the mini-tunnel, near $5^{\circ} \mathrm{C}\left(4^{\text {th }}\right.$ week of April), which probably reduced the root starting.

Influence of temperature during the organogenesis of adventitious roots was observed on cuttings of Pinus elliottii var. elliottii Engelm.x Pinus caribaea var. hondurensis (Sénécl) Barr. et Golf., where low temperatures influenced the survival of the cuttings, although but reducing the percentage of rooting (Rasmussen et al. 2009). In contrast, high temperatures can induce water deficit and trigger numerous cellular processes that affect cycle and cell division (Costa et al. 2013). High temperatures alter the metabolism of the propagules and may lead to the denaturation of enzymes with reduced absorption of nutrients that ultimately reduce the rhizogenic capacity of the tissues and promote the callus induction at the base of the propagules (Trueman et al. 2013). The lowest rooting at the end of the evaluations for most clones in GIF may be related to the higher maximum temperature in this environment (figure 1), which was over $35^{\circ} \mathrm{C}$ in some moments. Sensitivity to deleterious effects in high temperature conditions may also be related to the genetic variation existing in the species (Ahuja 2009), adaptive characteristics of each genotype (Hartmann et al. 2011) or even by epigenetic factors (Allavena and Rossetti 1986).

In general, the GIF showed average temperature (figure 1) closer to those indicated for the rooting of subtropical or tropical species $\left(20-25^{\circ} \mathrm{C}\right)$, mainly Eucalyptus spp. (Brondani et al. 2018). However, the fact that sequoia originates from colder areas with a high thermal variation (Olson et al. 1990), lower temperatures or with larger thermal variation between day and night can represent a benefit to the rooting of the species, such as seen for some species of conifers (Hartmann et al. 2011).

Each species requires a distinct temperature range, in which optimal adventitious rooting can be achieved. The average, maximum and minimum temperatures of the day, at determined time intervals, are parameters that must be 
considered in the propagation environment, being adapted for each species, hybrid or clone. Different species have different preferences in the rooting process. Corrêa and Fett-Neto (2004) observed in Eucalyptus saligna Smith the range of 25 to $30{ }^{\circ} \mathrm{C}$, while for Eucalyptus globulus Labill. the ideal average temperature is around $20^{\circ} \mathrm{C}$.

With the exception of clone A113, the others had a higher rooting at the end of the experiment (93 days) for the mini-cuttings kept in the mini-tunnel. This fact (most rooting in the mini-tunnel) can be explained by the maintenance of higher humidity in the mini-tunnel environment, as well as the damage to the process due to the high temperatures, as previously mentioned. Although the GIF has moisture content close to or higher than $80 \%$, there seems to be larger adaptation of the species to higher levels of this factor. Humidity is one of the external factors that most contribute to the occurrence of rooting in the cuttings, and its maintenance is recommended over 80 $\%$, thus preserving the turgescence of the propagules. According to Hartmann et al. (2011), plastic coverings in the rooting environment are recommended to maintain high humidity by forming a film of water vapor on the leaves. In case of wilting or dehydration of mini-cuttings, even for a short period, the chance of rooting is reduced drastically, and may lead only to the formation of calluses.

The use of mini-tunnels in vegetative propagation has increased in recent years, mainly in the mini-cutting of species of the genus Eucalyptus, promoting acceleration and elevation of rooting indices. Despite this, the most common use of these structures is in the coverage in the clonal minigarden (Batista et al. 2015). The use of simple mini-tunnels, such as those used in this study, for the maintenance of cuttings/mini-cuttings during the rooting process can be an inexpensive and easily installed alternative. Due to the results obtained in the rooting of sequoia and the data of humidity and temperature observed, it is possible to recommend the use of this structure for the most varied species, and the type and interval of the irrigation should be adjusted.

Corroborating with the results of the present study, where the mini-tunnel resulted in high rooting rates, Brondani et al. (2018) working with Corymbia citriodora (Hook.) K.D. Hill et L.A.S. Johnson, E. urophylla S.T. Blake and E. benthamii Maiden et Cambage, also obtained better rooting of micro-cuttings maintained in a mini-tunnel kept in the shade house. Studying the effect of minitunnels in the propagation of cuttings of Ficus carica L., Pipattanawong et al. (2008) found an increase in temperature and humidity with the use of the structure, a fact that promoted the early formation of calluses, shoots and roots. In Hamelia patens Jacquin (Nour and Elgimabi 2009) and Citrus limettioides Tan. (Hussain et al. 2016) better rooting results of cuttings were also found when they were kept in mini-tunnels with plastic cover. All the studies related the improvement in the rooting to higher humidity obtained with the use of the plastic structures, such as mini-tunnels.

The rooting of mini-cuttings and the number of roots were not significant for all clones. From the root initiation until the end of the evaluations (93 days) it was possible to observe differences, more pronounced in the clone A227 by the difference between the sites, and clone A140 by the precocity in the root initiation and stabilization. It can be observed that the genotype capacity and speed of rooting of minicuttings is similar to that found by Mankessi et al. (2009) and Oliveira et al. (2012) in species of the genus Eucalyptus.

The rooting velocity of mini-cuttings indicates differences among the clones regarding the rhizogenic process, reflecting distinction in the ideal time of permanence of the mini-cuttings in the rooting house. Results showing genotypic differences were also obtained in work with different progenies of Anadenanthera macrocarpa (Benth.) Brenan (Dias et al. 2012) and Eucalyptus grandis Hill (ex Maiden) clones (Melo et al. 2011).

It is known that the process of rooting in woody species is genotype dependent. Different species, hybrids and clones of the same parent may require different cultivation conditions and, consequently, varied indices and rooting processes (Mokotédi et al. 2000). The formation of adventitious roots in mini-cuttings can be directly and indirectly controlled by some genes (Silva et al. 2012), as SCARECROW and SCARECROW-LIKE (Sanchez et al. 2007), PtRR13, PtAIL1, PtAGL16 and PtMYB36 (Rigal et al. 2012) resulting in a low auxin level or lack of co-factors of rooting. The genetic determination in rooting is known for several conifers, such as Pinus taeda L., Larix sp, Tsuga heterophylla Raf. and Pinus elliottii Englem $\times$ P. caribaea var. hondurensis (Shepherd et al. 2005). This knowledge of genetic effect is directly related to the success or failure of plants production through mini-cuttings, since there may be premature discarding of some clones because they present a slower root emission.

An important fact in the vegetative propagation of sequoia is the formation of calluses in mini-cuttings. In this study, the presence of callus was higher in the mini-tunnel than in GIF. This fact can be attributed to larger temperature oscillation in mini-tunnel environment. However, callus formation is common in the vegetative propagation of conifers (Hartmann et al. 2011) mainly in sequoia (Navroski et al. 2015). In addition, there seems to be a genetic effect interacting with environmental effect on rooting, evidenced by the low appearance of callus in clone A140, mainly in the GIF environment. Other clones (mainly A228) present almost obligatory formation, for later rooting process.

It is important to consider that callus and root formation are independent processes, and the simultaneous occurrence is derived from the dependence of similar internal and environmental conditions (Goulart et al. 2014). However, in some plants callus formation may be a precursor to adventitious root formation as is commonly the case in sequoia.

The development of rooting, obtained through visual weekly frequency observations, shows that the process of cell differentiation is rapid for the species. After 15 days of planting it is possible to observe the appearance of callo- 
genic structures at the base of mini-cuttings. As described by Salvador (2011), with the preparation of a mini-cutting, from the longitudinal or bevel cut made at its base, a lesion occurs both in the tissues of the xylem and in the phloem, resulting in a trauma followed by a cicatrization process, forming then a suberin cover that reduces dehydration in the injured area. In this region a mass of disorganized parenchyma cells is formed, with little differentiation and in different stages of lignification, called callus.

In the process of rooting mini-cuttings, generally the higher and faster the degree of cell differentiation, the better the possibility of adventitious rooting of the species (Dias et al. 2012). This fact was observed in sequoia, since, from the $4 \mathrm{t}^{\mathrm{h}}$ week, an increase in the growth of the callogenic structures was observed, involving practically the whole radius of the base of the mini-cutting (figure 5B), however without rooting.

Sequoia rooting usually starts with the appearance of a root, followed by the emergence of others after a few days. In the beginning, few thick roots emerge, often arising from callogenic structures, although, they may also arise from woody tissues. The process evolves with the appearance of new roots and, mainly, secondary roots. This type of root, thinner, is desirable because it exhibits a higher absorption of water and nutrients (Freitas et al. 2009) and improves the structuring of the substrate.

Finally, as observed by the mini-cutting rooting percentage, it is possible to keep some clones for less time in the mini-tunnel or GIF. However, as visualized in the rooting process, it is recommended to maintain them for up to 90 days, to improve the quality of rooting and, especially, for the formation of thin roots.

\section{CONCLUSIONS}

The clones tested show different rooting speeds, with high average occurring mainly between 50 and 60 days after mini-cutting. The rooting environment presents a difference in the rooting process, being earlier in the GIF, nevertheless with a higher percentage in the mini-tunnel at the end of the evaluation. The number of roots was influenced by the clones and the two evaluated environments, presenting a higher formation of new roots between 70 and 80 days after mini-cutting.

The use of a mini-tunnel is indicated for the rooting of mini-cuttings of Sequoia sempervirens for its low cost and good rooting results. It is recommended to maintain them in this environment for a period of 90 days for proper root formation.

\section{ACKNOWLEDGMENTS}

The authors would like to thank Coordenação de Aperfeiçoamento de Pessoal de Nível Superior (CAPES) and Conselho Nacional de Desenvolvimento Científico e Tecnológico $(\mathrm{CNPq})$ for the scholarship awarded.

\section{REFERENCES}

Ahuja MR. 2009. Genetic constitution and diversity in four narrow endemic redwoods from the family Cupressaceae. Euphytica 165(1):5-19. DOI: $\underline{10.1007 / \mathrm{s} 10681-008-9813-3}$

Akaike H. 1973. Information theory and an extension of the maximum likelihood principle. In Petrov BN, F Csaki eds. Second International Symposium on Information Theory. Budapest, Hungary. Academiai Kiado. p. 267-281.

Allavena A, L Rossetti. 1986. Micropropagation of bean (Phaseolus vulgaris L.): Effect of genetic, epigenetic and environmental factors. Scientia Horticulturae 30(1):3 7-46. DOI: $\underline{10.1016 / 0304-4238(86) 90079-8}$

Almeida EFA, PB Luz, MA Lessa, PDO Paiva, CJB Albuquerque, MVC Oliveira. 2008. Diferentes substratos e ambientes para enraizamento de mini-ixora (Ixora coccinea "compacta"). Ciência e Agrotecnologia 32(5):1449-1453. DOI: 10.1590/ $\underline{\mathrm{S} 1413-70542008000500014}$

Batista AF, GA Santos, LD Silva, FF Quevedo, T Assis. 2015. The use of mini-tunnels and the effects of seasonality in the clonal propagation of Eucalyptus in a subtropical environment. Australian Forestry 78(1):65-72. DOI: 10.1007/s10681-0089813-3 10.1080/00049158.2015.1039162

Boe KN. 1974. Sequoia sempervirens (D. Don) Endl. In Schopmeyer CS ed. Seeds of woody plants in the United States. Agriculture handbook 450. USDA Forest Service, Washington, DC, USA. p. 764 -766.

Borges SR, A Xavier, LS Oliveira, LA Melo, MA Rosado. 2011. Enraizamento de miniestacas de clones híbridos de Eucalyptus globulus. Revista Árvore 35(3):425-434. DOI: 10.1590/ $\underline{\text { S0100-67622011000300006 }}$

Brondani GE, LS Oliveira, ER Konzen, ALL Silva, JL Costa. 2018. Mini-incubators improve the adventitious rooting performance of Corymbia and Eucalyptus microcuttings according to the environment in which they are conditioned. Annals of the Brazilian Academy of Science 90(2 Suppl. 1):2409-2423. DOI: $10.1590 / 0001-3765201720170284$

Brondani GE, F Grossi, I Wendling, LF Dutra, M Araujo. 2010. Aplicação de IBA para o enraizamento de miniestacas de $E u$ calyptus benthamii Maiden \& Cambage x Eucalyptus dunnii Maiden. Acta Scientiarum Agronomy 32(4):667-674. DOI: $\underline{10.4025 / \text { actasciagron.v32i4.4879 }}$

Corrêa LR, AG Fett-Neto. 2004. Effects of temperature on adventitious root development in microcuttings of Eucaltptus saligna Smith and Eucaltptus globulus Labill. Journal of Thermal Biology 29(1):315-324. DOI: 10.1016/j.jtherbio.2004.05.006

Costa CT, MR Almeida, CM Ruedell, J Schwambach, FS Maraschin, AG Fett-Neto. 2013. When stress and development go hand in hand: main hormonal controls of adventitious rooting in cuttings. Frontiers in Plant Science 4(1):1-19. DOI: $10.3389 /$ fpls.2013.00133

Dias PC, A Xavier, LS Oliveira, HN Paiva, ACG Correia. 2012. Propagação vegetativa de progênies de meios-irmãos de angico-vermelho (Anadenanthera macrocarpa (Benth) Brenan) por miniestaquia. Revista Árvore 36(3):389-399. DOI: 10.1590/S0100-67622012000300001

Freitas TAS, DG Barroso, LS Souza, JGA Carneiro. 2009. Efeito da poda de raízes sobre o crescimento das mudas de eucalipto. Ciência Florestal 19(1):1-6. DOI: 10.5902/19805098414

Gale AW. 1962. Sequoia sempervirens; its establishment and uses in Great Britain. Quarterly Journal of Forestry 56(2):126-137. 
Garrido G, JR Guerrero, EA Cano, M Acosta, J Sánchez-Bravo. 2002. Origin and basipetal transport of the IAA responsible for rooting of carnation cuttings. Physiologia Plantarum 114(2):303-312. DOI: 10.1034/j.1399-3054.2002.1140217.x

Goulart PB, A Xavier, L Iarema, WC Otoni. 2014. Morfoanatomia da rizogênese adventícia em miniestacas de Eucalyptus grandis $x$ Eucalyptus urophylla. Ciência Florestal 24(3):521-532. DOI: $10.5902 / 1980509815721$

Hartmann HT, DE Kester, FT Davies Jr, RL Geneve. 2011. Plant Propagation: principles and practices. 8. ed. New Jersey, USA. Prentice Hall. 915 p.

Hussain I, G Nabi, H Rehman, K Shah, S Ali. 2016. Effect of different environmental condition on different types of Sweet lime cuttings. Pure and Applied Biology 5(2):298-302. DOI: 10.19045/bspab.2016.50038

Luna T. 2008. Vegetative Propagation of Coastal Redwood (Sequoia sempervirens (Lamb. ex D. Don) Endl.). Native Plants Journal 9(1):25-28. DOI: 10.2979/NPJ.2008.9.1.25

Mankessi F, A Saya, C Baptiste, S Nourissiermountou, O Monteuuis. 2009. In vitro rooting of genetically related Eucalyptus urophylla $\times$ Eucalyptus grandis clones in relation to the time spent in culture. Trees 23(5):931-940. DOI: 10.1007/s00468009-0335-y

Mcmahon TV, CD Hung, SJ Trueman. 2014. Clonal maturation of Corymbia torelliana x C. citriodora is delayed by minimal-growth storage. Australian Forestry 77(1):9-14. DOI: 10.1080/00049158.2013.862160

Melo LA, A Xavier, HN Paiva, SR Borges. 2011. Otimização do tempo necessário para o enraizamento de miniestacas de clones híbridos de Eucalyptus grandis. Revista Árvore 35(4):759-767. DOI: 10.1590/S0100-67622011000500001

Metcalf W. 1924. Artificial reproduction of redwood (Sequoia sempervirens). Journal of Forestry 22(8):873-893. DOI: 10.2979/NPJ.2008.9.1.25

Mokotedi MEO, MP Watt, NW Pammenter, F Blakeway. 2000. In vitro rooting and subsequent survival of two clones of coldtolerant Eucalyptus grandis X Eucalyptus nitens Hybrid. Hortscience 35(6):1163-1165. DOI: 10.21273 / HORTSCI.35.6.1163

Navroski MC, MO Pereira, AF Hess, R Silvestre, AC Ângelo, AJ Fazzini, AA Alvarenga. 2015. Resgate e propagação vegetativa de Sequoia sempervirens. Floresta 45(2):383-392. DOI: 10.5380/rf.v45i2.35407

Nour ME, E Elgimabi. 2009. Improvement of propagation by hardwood cuttings with or without using plastic tunnel in (Hamelia patens). World Journal of Agricultural Sciences 5(5):522-524.

Oliveira LS, A Xavier, PC Dias, ACG Correia, SR Borges, EK Takahashi, HN Paiva. 2012. Enraizamento de miniestacas e microestacas de clones de Eucalyptus urophylla x E. globulus e de Eucalyptus grandis $x$ E. globulus. Scientia Forestalis 40(96):507-516.

Olson Jr, DF, DF Roy, GA Walters. 1990. Sequoia sempervirens (D. Don) Endl. Redwood. In Burns RM, Honkala BH eds. Silvics of North America. U.S. Department of Agriculture, Agricultural Handbook. p. 541-551.

Pipattanawong N, S Tiwong, B Thongyean, R Darak, P Thamin, W Techa. 2008. Improvement of propagation by hardwood cut- tings with and without using plastic pavilions in fig (Ficus carica L.) Kasetsart Journal: Natural Science 42(2):207-214.

Rasmussen A, TE Smith, MA Hunt. 2009. Cellular stages of root formation, root system quality and survival of Pinus elliottii var. elliottii $x$ P. caribaea var. hondurensis cuttings in different temperature environments. New Forests 38(3):285-294. DOI: $10.1007 / \mathrm{s} 11056-009-9147-6$

Rigal A, Yordanov YS, Perrone I, Karlberg A, Tisserant E, Bellini C, Busov VB, Martin F, Kohler A, Bhalerao R, Legué V. 2012. The AINTEGUMENTA LIKE1 homeotic transcription factor PtAIL1 controls the formation of adventitious root primordia in poplar. Plant Physiology 160: 1996. DOI: $10.1104 / \mathrm{pp} .112 .204453$

Roy DF. 1966. Silvical characteristics of redwood (Sequoia sempervirens [D. Don1 Endl.). Berkeley, USA. USDA Forest Service, Pacific Southwest Forest and Range Experiment Station. 20 p. (Research Paper PSW-28).

Salvador TL. 2011. Caracterização morfológica de genótipos e formação de raízes em estacas caulinares de pinheira (Annona squamosa L.). Dissertação (Mestrado em Produção vegetal). Rio Largo-Alagoas, Brasil. Universidade Federal de Alagoas, Centro de Ciências Agrárias. 104 p.

Sanchez C, Vielba JM, Ferro E, Covelo G, Sole A, Abarca D, de Mier BS, Diaz-Sala C. 2007. Two SCARECROW-LIKE genes are induced in response to exogenous auxin in rooting-competent cuttings of distantly related forest species. Tree Physiology 27:1459-1470. DOI: 10.1093/treephys/27.10.1459

Shepherd M, R Mellick, P Toon, G Dale, M Dieters. 2005. Genetic control of adventitious rooting on stem cuttings in two $P i$ nus elliottii $\times$ P. caribaea hybrid families. Annals of Forest Science 62(5):403-412. DOI: 10.1051/forest:2005036

Silva LFO, AF Oliveira, R Pio, CR Zambon, DL Oliveira. 2012. Enraizamento de estacas semilenhosas de cultivares de oliveira. Bragantia 71(4):488-492. DOI: $10.1590 /$ S0006$\underline{87052012000400006}$

Stuepp CA, KC Zuffellato-Ribas, HS Koehler, I Wendling. 2015. Rooting mini-cuttings of Paulownia fortunei var. mikado derived from clonal mini-garden. Revista Árvore 39(3):497504. DOI: $\underline{10.1590 / 0100-67622015000300010}$

Stuepp CA, GP Pereira, LM Zem, MLP Peña, PMC Bueno, V Spader, KC Zuffellato-Ribas, GM Rosa. 2013. Enraizamento de melaleuca: influência da altura de coleta das estacas e aplicação de IBA. Colloquium Agrariae 9(1):01-09. DOI: 10.5747/ca.2013.v09.n1.a083

Trueman SJ, TV Mcmahon, M Bristow. 2013. Production of cuttings in response to stock plant temperature in the subtropical eucalypts, Corymbia citriodora and Eucalyptus dunnii. New Forests 44(2):265-279. DOI: 10.1007/s11056-012-9315-y

Vieira Neto J, AF Oliveira, ED Gonçalves, HA Mesquita, LFO Silva, NC Oliveira, R Pio, DF Silva. 2010. Enraizamento de estacas semilenhosas de oliveira em estufa baixa: alternativa para o pequeno produtor. Belo Horizonte, Brasil. EPAMIG (Circular Técnica 78).

Wendling I, S Trueman, A Xavier. 2014. Maturation and related aspects in clonal forestry, part II: reinvigoration, rejuvenation and juvenility maintenance. New Forests 45(4):473-486. DOI: $10.1007 / \mathrm{s} 11056-014-9415-\mathrm{y}$ 